\title{
Indonesian misadventure:
}

A US mining giant's clash

West Papuan tribesmen take on the operations of Freeport McMoran, the company that runs the world's largest goldmine and third-largest copper mine. The lessons for Papua New Guinea's resource developers are sobering.

\section{By EYAL PRESS}

ON 10 MARCH 1996, the Indonesian province of Irian Jaya, or West Papua, erupted in a series of riots aimed at halting the operations of Freeport-McMoran, a New Orleans-based mining company that runs the world's largest gold mine and third-largest copper mine on the western half of the island of New Guinea.

The three-day rebellion began after a vehicle driven by a Freeportemployee accidentally struck a local tribesman, Wilenus Kogoya. Rumors spread that the man had been killed, whereupon hundreds of indigenous people armed with sticks, spears, and knives began attacking Freeport facilities, ransacking buildings, breaking windows, damaging anenvironmental lab and scores of company offices and homes. They eventually forced the temporary closure of both the mine in Tembagapura, and the local airport in neighboring Timika, where rioters rushed to meet the incoming plane of Freeport chief executive officer James Robert ("Jim Bob") Moffett.

'We fight against Jim Bob Moffett, Freeport, and the government,' read a statement from local people connected to the protesters. 'We fight because our rights are not recognised, our resources are extracted and destroyed while our lives are taken.' A spokesperson for the Amungme, Komoro, Dani, and Moni tribes of the region addressed the Freeport CEOdirectly: 'You and your workers live in luxury on our property. We, who own the rights to the properly, sleep on rubbish. Therefore, from today, we don't give you permission for this company, and close it.'

On March 14, as the rioting calmed, indigenous leaders met with Moffett. 
EYAL PRESS

Mama Yosepha, a woman who was forced to sit inside a Freeport shipping container by Indonesian troops last year, said, 'My son Moffett, in the past I put you inside my noken [a bag used by Amungme women to carry babies and piglets]. I took you with me wherever I went, but I did not realise that you actually suck my blood until it's all drained, and I remain only in bones without flesh. Now, I pick you out of my noken and will throw you far away' - at which point she hurled her noken to the floor. Moments later, she and others presented Moffett with a list of demands, calling for more jobs for local people, a right to control what happens on their land, and the dismantling of Freeport's security force, which is embroiled in allegations of human-rights abuse.

Situated on the eastern fringe of the vast Indonesian archipelago that stretches across much of Southeast Asia, Irian Jaya seems as far removed as possible from the epicenter of global politics and commerce. But in this day and age, no place is remote enough. Cursed with an abundance of timber, copper, and other natural resources Irian Jaya has become a magnet for companies like Freeport, which extract the riches while trampling on the rights of native peoples.

Irian Jaya is by no means unique. Indigenous people of disparate regions are fighting an enemy of common form. The Amungme, Komoro, and other native tribes in Irian Jaya-like the Ogoni people struggling against Royal Dutch Shell in Nigeria; the Quichua and Hourani confronting Texaco in Ecuador; the Zapatistas in Chiapas - are at the front lines of a battle between indigenous people and transnational corporations. It is a battle over environmental justice, human rights the preservation of indigenous culture, the right to control development, and the need for a more equitable distribution of wealth fundamental issues that Western corporations have long assumed could go ignored within the friendly confines of Third World dictatorships.

In this respect, it is hard to rival Indonesia, which granted Freeport the formal right to exploit Irian Jaya's mineral resources in 1967. This was two years before Indonesia formally declared the region its twenty-sixth province, following an Act of Free Choice in which 1,025 representatives preselected by the Indonesian government were allowed to 'choose' Indonesian rule on behalf of 800,000 people. Indonesia has since become the glittering star in Southeast Asia's market economy, luring US corporations with cheap labor, abundant resources, and a government that rules in capital's favor with an iron fist.

Jim Bob Moffett refers to General Suharto as a 'compassionate man' - this of an autocrat who slaughtered some 500,000 people upon coming to power in 1965, and has since killed 200,000 during the illegal occupation of East Timor. Suharto obliges Moffett by keeping a heavy troop presence near the Freeport mine. For Jakarta, this 'vital national project' generated $\$ 380$ million in revenue 
last year alone, and rests atop reserves worth an estimated $\$ 60$ billion. Freeport says the Indonesian military in Irian Jaya 'serves the role that the police would serve in a more developed area.'

The latest State Department annual Report on Human Rights, however, notes that this 'police' force routinely subjects civilians to 'kicking with heavy boots; beating with fists, sticks, stones, and rifle butts; starvation; shackling thumbs, arms, and legs; taping eyes shut; stamping on hands; and forcing victims to stand for prolonged periods while bearing heavy weights.'

In the past year, allegations have implicated Freeport itself in some of these abuses. In April 1995, the Australian Council for Overseas Aid (ACFOA) released Trouble at Freeport, a report detailing the killing or disappearance of 22 civilians and 15 alleged guerrillas in and around the mine since June 1994. Prepared in Irian Jaya by local people, the report alleges that Indonesian troops carried out abuses in Freeport facilities, and that Freeport security cooperated with the army during some incidents, including a Christmas Day, 1994, attack that killed three people and in which five others disappeared.

Freeport vehemently denies any involvement; the company points to investigations by both the Catholic Church and Indonesian government allegedly clearing it of any responsibility. But local people, along with Amnesty International and Human Rights Watch, are calling for a full, independent investigation into Freeport's role.

Freeport's environmental record is also cause for concern. It reportedly dumps 115,000 tons of tailings (refuse from the mining process) daily onto the pristine environment below the mine. Critics have long complained that the company has poisoned the waters and damaged the lush surrounding rainforest. In October, the U.S. Overseas Private Investment Corporation (OPIC), which provides political-risk insurance to American companies operating abroad, canceled Freeport's policy due to concerns about the impact of its project. Although Freeport has since utilised its political clout to have its OPIC insurance temporarily restored, reports of atrocities and environmental problems at the mine prompted the company to launch a huge public-relations campaign.

Freeport took out numerous full-page ads in The New York Times vaunting its overseas operation as a 'model of development'. THE TRUTH IS PUTTING ON ITS SHOES, the ads declared. The company flew two dozen investment analysts out to Irian Jaya, portraying the situation as stable. It produced a glowing company video presenting life at the mine as a paradise for all. Behind the scenes, top executives threatened critics with lawsuits and pulled political strings to muzzle independent groups. Orchestrating this performance was Planit Communications, a collection of former journalists and PR hacks 
EYAL PRESS

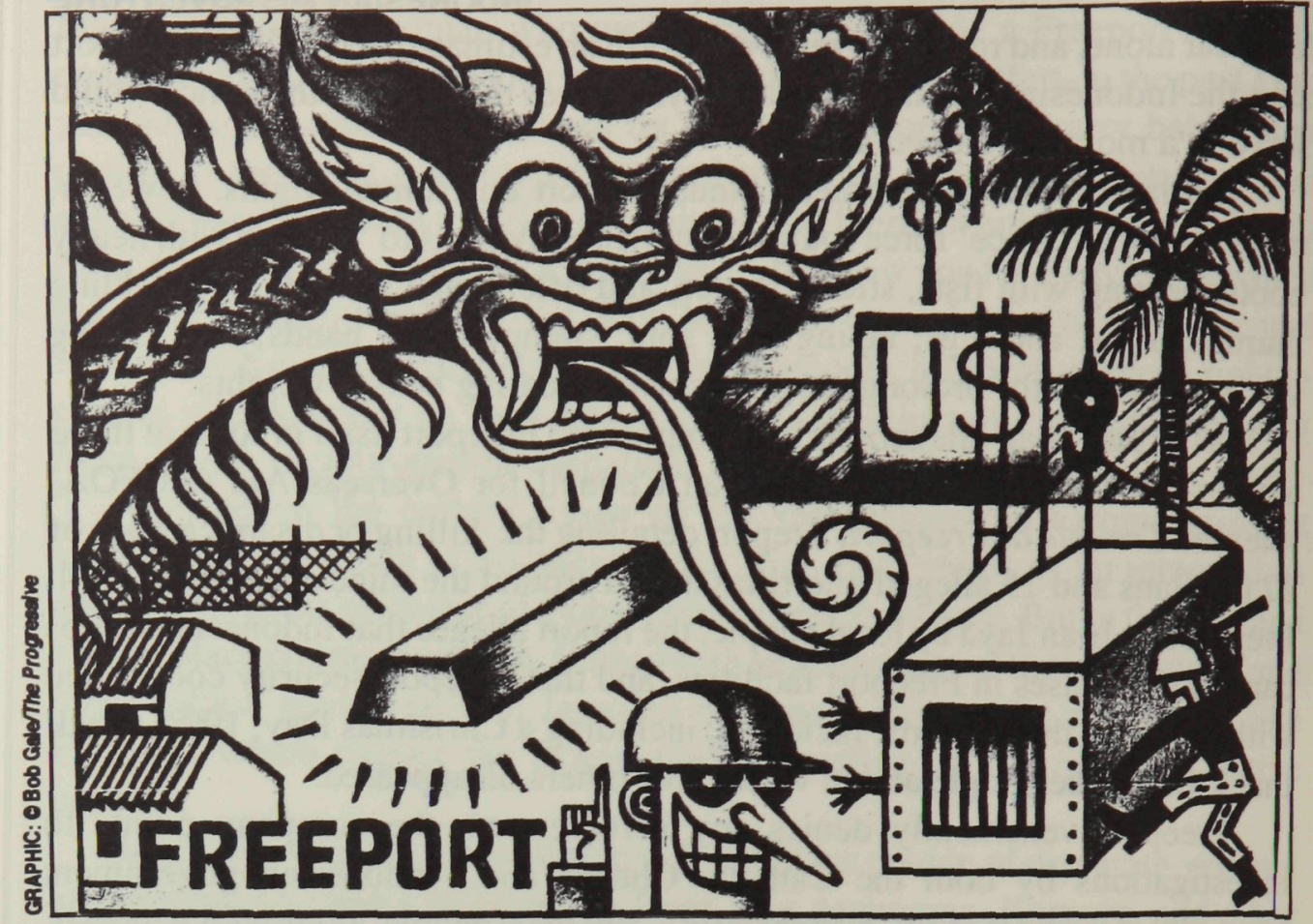

brought together by Freeport to handle media relations.

Planit's promotional material boasts: 'If your name is fast becoming mud in the public eye, if your project reels in the wake of public assault, Planit will initiate a proactive communications campaign to truthfully inform your community and decision-makers so that your story - not "their story" - leads public opinion.'

Then the riots erupted. Two weeks later Planit closed down. As a Freeport spokesperson now grudgingly concêdes, 'Obviously we're not doing this perfectly or this [the rioting] wouldn't have happened.'

The problem runs far deeper than anyone at the company will admit. Freeport's recent ads in.The New York Times trumpet the 'roads, schools, and hospitals' the company has built 'to help make a better life for our employees and their community'. Yet only 15 percent of Freeport's roughly 15,000 employees are locals, and most of them occupy the lowest-level jobs. The Amungme, a highland people, have been displaced from their land in a series of forced removals that began shortly after Freeport launched operations in 1973. Although a 1974 agreement between the company and some local tribal leaders gave Freeport formal permission to launch operations, many Amungme feel the deal went through without their input or control.

'The local communities have lost their rights,' wrote Tom Beanal,chairman of LEMASA, the Amungme tribal council, in a 1993 letter to Freeport. 'The 126 PACIFIC JOURNALISM REVIEW 3:2 1996 
environment has been severely degraded ... Local people's self-respect has been eroded, cultural norms have been abandoned, all as a result of Freeport's mining activities and blatant disregard.' According to Beanal, the smiling faces in Freeport's PR videos mask the grim reality of residents living in clapboard shacks, children scrounging for food, and communities ravaged by malnutrition and preventable disease - this while Freeport's privileged employees enjoy modern apartments, travel benefits, and more.

'Freeport is digging out our mother's brain,' says one Amungme leader, referring to the mountains being blasted to extract ore. The tons of tailings dumped daily onto the ecosystem have allegedly destroyed roughly twenty-six square miles of once-verdant rainforest, ruining palm trees that are the source of sago, a traditional staple of local people's diets. The tailings have also reportedly clogged the Aghawagon and Ajkwa rivers that pass below. Freeport steadfastly defends its environmental record in Irian Jaya, and denies any part in the devastation of the local environment.

WALHI, a Jakarta-based environmental group, has long been pushing Freeport to neutralize its tailings before disposal and open the areato independent monitoring - standard practice for mines in the rest of the world. The group has apparently asked for too much. On September 7, 1995, Paul Murphy, executive vice president of Freeport Indonesia, sent a letter to the U.S. Agency for International Development requesting that it cut off all funding to the "newly radicalised' WALHI, whose crimes included 'openly affiliat[ing] with radical international NGOs [nongovernmental organizations] such as Earth First!, Friends of the Earth, Global Response and Greenpeace,' 'organis[ing] protests,' and using 'access to the media to manipulate public discourse.'

Only a month and a half later, OPIC seemed to confirm everything the 'newly radicalised' WALHI had been saying for years when it cancelled Freeport's US\$100 million risk insurance. After a November story in the New' Orleans Times-Picayune speculated that OPIC's decision was based on environmental problems, Freeport CEO Moffett stormed into the paper's offices to demand that it print a correction, insisting OPIC's decision was based on future considerations which 'might pose difficulties'. Hours later, the Times-Picayume and others received a letter from OPIC to Freeport (dated October 10, and released under the Freedom of Information Act) stating that 'massive deposition of tailings' from Freeport's operation 'has degraded a large area of lowland rainforest', posing 'unreasonable or major environmental, health or safety hazards with respect to the rivers. .. the surrounding terrestrial ecosystem, and the local inhabitants". The OPIC letter also cited problems associated with 'acid mine drainage from overburden and tailings ... toxic metals ... and the mismanagement of solid and hazardous wastes at the site'. 


\section{EYAL PRESS}

Just six months later, in April 1996, OPIC restored Freeport's insurance through the end of the year in exchange for the company's creation of a $\$ 100$ million environmental trust fund, to accrue over 40 years. It's not difficult to guess why. Since 1984, Freeport's nimble PAC has disbursed money to threefourths of the Senate and one-quarter of theHouse. For example, $\$ 9500$ has gone to Representative Billy Tauzin, Democrat of Louisiana, and $\$ 6000$ to Senator John Breaux, Democrat of Louisiana. Immediately after OPIC canceled Freeport's policy, Tauzin rushed out several op-eds bashing the decision, warning that the agency (which is up for Congressional reauthorisation in the fall) was putting its 'bipartisan backing' at risk.

Senator Breaux, meanwhile, temporarily blocked action on a Senate review of a Treasury Department nominee who had served on OPIC's board of directors. The Clinton Administration also got an earful from Henry Kissinger, who made $\$ 400,000$ last year as a consultant for the company.

On the very day that OPIC officials announced the settlement and lauded recent improvements at the mine, Tapol, a human-rights group in London, reported that Indonesian soldiers had raided the offices of a group representing the Amungme people, 'adding to the sense of intimidation and crisis' enveloping the area. Since the March riots, thousands of Indonesian troops have been swarming around the mine.

To the Amungme, this is a familiar story. In 'normal' times, roughly 70 Indonesian military personnel permanently patrol the area around the mine, buttressing a vast Freeport security apparatus. Freeport insists there is a strict division between the two, a point bearing added emphasis since last year's publication of the Australian Council for Overseas Aid human rights report. On Christmas Day of 1994, that report says, Indonesian military and Freeport security interrupted a peaceful flag-waving ceremony and opened fire, killing three civilians, disappearing five, and torturing 13 others.

Freeport categorically rejects this charge, and says its own security force does not even carry guns. John Matthews, the pseudonym of an American who recently passed through the mine, was told otherwise by an English-speaking Freeport employee (whom Matthews wishes not to name).

'As we stood in the highest security post inside the mine, surrounded by men carrying guns, this employee told me that the only way to tell the difference between Indonesian soldiers and Freeport security guards is that the soldiers carry M16s and Freeport security carries AK-47s,' Matthews says.

One morning, Matthews was awakened by an entourage from the mine firing a gun into the air (Matthews has a picture of this group smiling and holding a gun, which has the characteristic curve of an AK-47). 'When I told my acquaintance at Freeport about our wake-up call,' Matthews says, 'he guessed 
that it was Freeport security.'

Like others who have visited the mine without being shepherded through by the company, Matthews found it difficult to distinguish between company security officers and the military. 'To me, there was absolutely no visible difference. The company works with the troops and the troops work with the mine, and their interests are aligned, so unless you're really splitting hairs, there's no effective difference.'

Several environmental groups, including the International Rivers Network, the Sierra Club, and Friends of the Earth, have urged Freeport to press Jakarta to drastically reduce the military presence around the mine, noting the company 'shares a moral responsibility for the recent tragic events since the military is protecting Freeport operations, and Freeport provides the military with logistical support and equipment.'

Freeport admits it is under contract to provide the military with food and equipment, including shipping containers that, as a Catholic Church report gruesomely described last year, have been used by the Indonesian military as torture chambers. Mama Yosepha, the woman who hurled Moffett from her noken after the riots, survived detention in such a container. So did another, who explains in the Church report: 'They took turns beating and kicking us. They stripped us stark naked. I only could look on ... afraid and powerless.'

Freeport, though, insists that both the Catholic Church report and a subsequent one by the Indonesian Human Rights Commission conclusively show the company is not to blame for any human-rights abuses. It quotes Bishop H.F.M. Munninghoff, author of the Church report, who says, 'My report is not about Freeport. Freeport is not at all involved in these violations of human rights.'

Freeport enlarged, boxed, and highlighted this statement in its New York Times ads, and also had it videotaped. But according to Theo van den Broek, a Franciscan missionary who heads the diocese office at Jayapura and was present when Munninghoff spoke, Freeport has twisted the statement and taken it out of context. Neither Munninghoff nor others at the Church, he says, believe that their report investigated the full range of abuses near the mine, or sought to establish who is responsible.

'The bishop's report is limited to a certain number of cases that we could get facts about. In one or two of the cases, it is clear that Freeport material has been used. This should be investigated. Exactly who is responsible is an open question.'

In a letter to authorities in both Irian Jaya and Jakarta prior to the recent riots, LEMASA, the Amungme tribal council, requested that a full investigation be conducted into abuses at the mine, presenting a long list of alleged atrocities. including several of those detailed in the ACFOA report. Adding to the 


\section{EYAL PRESS}

demands, a community worker who wishes to remain anonymous notes that after the riots, local people specifically asked Moffett to remove four Freeport security employees.

'The people say it's not just the army but Freeport security,' says the community worker. 'It's true that Freeport will deny it, but the victims are there, the families are there, and an investigation needs to take place. The American people should know about this. These are gross human-rights abuses.'

If a full investigation into Freeport's role ever does take place, it ought to begin by closely examining the events that precipitated the military's crackdown in late 1994. In November of that year, Freeport admits that it called in the military, claiming that one of its employees, Gordon Rumaropen, had been shot dead by a member of the Organisasi Papua Merdeka(OPM), an indigenous rebel movement that seeks independence from Indonesia. Articles in Business Week and elsewhere repeated Freeport's charge that Rumaropen was killed by OPM snipers without checking the facts.

Greg Roberts, an Australian journalist with the Sydney Morning Herald, did check them, and he learned that the person Freeport says witnessed the murder - an Australian named Pat Harris - believes Rumaropen was killed not by the OPM but by Indonesian military forces. Driving one morning, Harris says he heard gun shots and saw two Indonesians in camouflage - easily distinguishable from Papuans, who are dark-skinned and curly-haired. He turned around and found Rumaropen's body alongside an Indonesian base camp where Indonesian soldiers were standing around. When Harris told Freeport what he had seen, he sensed nobody was interested. During his visit to the mine, Roberts says he spoke with several Freeport employees who speculated that the incident was a convenient pretext for a crackdown.

Freeport has tried aggressively to clamp a lid on the truth. In the United States, Freeport threatened to sue seven individuals - including two reporters, three professors at the University of Texas in Austin, and the head of International Rivers Network - for repeating allegations about Freeport's involvement in human-rights abuses.

In Irian Jaya, Freeport took a different tack. On 13 April 1966, Freeport unveiled a package of initiatives designed to better the lives of the people of Irian Jaya. Among the initiatives is an 'Integrated Timika Development' plan, along with a new job-training centre to increase the number of locals in the company's employ. (The plan will be financed by 1 per cent of Freeport revenue over the next ten years - roughly $\$ 18$ million, which is less than half the $\$ 47$ million in salary and stock options granted Jim Bob Moffett alone in 1995.)

The nexı day, LEMASA denounced the plan. 'It fails to answer the roots of the problem between Freeport and the Amungme,' the council said. The plan 
does not provide a way for the Amungme to sustain their livelihood; nor does it offer "compensation for the damage inflicted on their environment, for their resources, and for the human-rights abuses to which they have been subjected.'

Having seen their land expropriated, their environment devastated, their brothers and sisters subjected to repression and abuse, the people of Irian Jaya want more than a trickle of the wealth that Freeport has extracted from their land. Like victims of corporate offences elsewhere, they seek some measure of justice and retribution as well. In a statement that echoes from Jakarta to Washington, from Irian Jaya to New Orleans, they've made it clear to the company that they will no longer pay for its profits with their lives.

On April 29, Tom Beanal of LEMASA filed a \$6 billion lawsuit against Freeport in a U.S. district court in New Orleans. The suit charges Freeport with responsibility for a range of human-rights and environmental abuses 'which have terrorised the tribal communities ... destroyed their natural habitats,' and resulted in the 'demise of a culture of indigenous people whose rights were never considered.' The company dismisses the suit as 'frivolous and opportunistic'.

(C) 1996 Eyal Press

$\square$ Eyal Press is a freelance writer based in New York. He previously wrote about Freeport-McMoran for The Nation. This article was originally published in the June 1996 issue of The Progressive. It is republished with permission. 